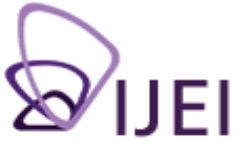

International Journal for Educational Integrity

\title{
Review \\ Stop plagiarism: A guide to understanding and prevention
}

\author{
Vibiana B. Cvetkovic and Katie E. Anderson (eds) (2010) \\ New York, NY: Neal-Schuman Publishers.
}

\author{
Margaret Wallace \\ Centre for Educational Development Innovation and Recognition \\ University of Wollongong \\ margaret_wallace@uow.edu.au
}

Who would not be attracted by a book title such as Stop Plagiarism: A Guide to Understanding and Prevention? If you are a teacher, learning advisor or librarian, any clues you can find to help prevent plagiarism would be welcome. If you do judge a book by its cover (or by those details that can be gleaned in the first few pages) you might be attracted or repelled by the fact that that it has such an assertive title and by the fact that it originates in the United States. Are your concerns well-founded?

Its stated purpose is to "help educators teach high school and undergraduate students about intellectual honesty" (p. 40). It is not a revised edition of an existing book, but is described as a sequel to a previous book, The Plagiarism Plague edited by Vibiana Bowman, 2004. Indeed, this book shares a co-editor; Vibiana B. is Vibiana Bowman Cvetkovic. The goal of Stop Plagiarism is to "update and reenergize the fight against plagiarism" (p. ix) by including many new authors "who represent the next generation of librarianship, the Web 2.0 professional" (p. ix). This sequel claims to better consider the implications of the Internet, Web 2.0 technologies and the $M$ (millennium) generation. There is something in the style of the Preface that could cause the reader to worry that this book is merely an exhortation to students to behave themselves and to stop being naughty. But it is more than that.

What is good about Cvetkovic \& Anderson's book is that it reminds us that issues of academic honesty and plagiarism exist in educational institutions across the developed world. The contributors attempt to locate the issue of plagiarism within a wider context of ideas about creativity, originality, scholarship, knowledge, and education. They ensure that the book deals with ways of understanding plagiarism as well as with remedies for it.

However, there is something rather wearing about the thesis proposed by the editors and the contributing authors that we are all involved in a "war" against plagiarism. There is talk of strategy, revolution, reinforcements, battle plans (pp. 47-48), tackling the problem on many fronts (p. 37), of inoculating against plagiarism (as if it is some sort of disease) (p. 151).

The content is laid out in a logical fashion with three main sections: "Understanding the Problem", "Finding Remedies", and "Practitioner's Toolkit". The section on "Understanding the Problem" provides reassurance to those seeking a sophisticated understanding of plagiarism because it is in this section that the contributing authors deal with matters such as the cultural understanding of issues such a originality and

The International Journal for Educational Integrity is available online at:

http://www.ojs.unisa.edu.au/journals/index.php/lJEl/

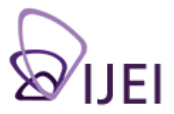


copying, the development of online businesses selling assignments and perceptions of plagiarism. This section includes a "student voice" with a chapter by an undergraduate student who exhorts teachers to discuss student writing and plagiarism more openly in class. It is in the chapter by Cvetkovic and Rodriguez that a key thesis of the book is outlined:

The contributors to this work have uniformly constructed their arguments on the premise that plagiarism is an act of intellectual dishonesty. This premise's logical corollaries are that plagiarism undermines academic integrity; the people who engage in such behaviour should be censured and punished; and educators are responsible for teaching the next generation of scholars that such behaviour is unacceptable. (p. 40)

Various media critics contend that the world has moved into a post-plagiarism era. The argument advanced goes like this: because information is web-based, fluid, hyperlinked, and collaboratively authored, citations to source documents are irrelevant; therefore, it is pointless for the Academy to continue to wage war on plagiarism. Is it time, therefore, to lay down arms? (p. 40). In response, the writers in this chapter then argue that citation and plagiarism do matter. They describe systems of citation as serving as "a genealogy chart for the ideas that authors contribute to the world of scholarship" (p. 46). I am persuaded by their argument, but I am still unsure about how the book proposes that we might more effectively teach this concept (and the skills to enact it) to students.

While not of direct relevance to readers outside the United States the chapters on "Plagiarism: The Legal Landscape" and "Professional Organizations'

Recommendations Regarding Intellectual Honesty" will be of interest to all readers. Although these chapters are interesting they are not of immediate assistance to the reader who is seeking help in teaching students about academic honesty. In fact, although the book claims to be relevant for high school and university teachers, the ideas and materials presented have a higher education emphasis and many high school teachers could find other, more immediately useful resources elsewhere.

My favourite part is Chapter 2 "The Onus of Originality: Creativity and Accomplishment in a Digital and Competitive Age". The author of this chapter, Laura Spencer, says:

While a proscribed behavior, such as plagiarism, is easy to engage in, rules prohibiting it are not in themselves typically sufficient to stop the behavior. A better approach is to create conditions under which the proscribed behavior makes no sense and confers no benefit.

This philosophy resonates very much with my own. Spencer's well-constructed chapter leads the reader through four key elements she considers to be "present in conditions that encourage intellectual honesty: originality, imitation, expertise, and engagement" (p. 15). This is the most thought-provoking chapter of the book and is well worth reading to broaden and challenge one's own ideas about originality and creativity. Spencer indicates that her aim is to "view plagiarism from unusual perspectives in order to highlight aspects of the practice, the better to help educators find new ways of thinking about the problem" (p. 26). As she puts it, "Plagiarists are missing out on all the fun. Plagiarism denies students who practice it opportunities to develop their own voice, expertise in a subject, and engagement in that subject" ( $p$. 26). Perhaps we need to re-discover the fun in teaching and learning in order to get to the essence of integrity in learning and teaching.

As a side comment I would like to note that the authors make allusions to cultural knowledge that might be difficult for an international audience (or one that is younger 
than the authors) to connect with. For example, on p. 146, at the end of the chapter on "Professional Organizations' Recommendations Regarding Intellectual Honesty", Kaufmann and Still write that "As the song says, they have a code that they can live by". Apart from the fact that there is no acknowledgement that this is a line from the lyrics of a song by Crosby and Nash, the use of such allusions in a "reference book" that presumably seeks an international (and therefore also multicultural and transgenerational) readership is inconsiderate. Fortunately, I recognised the likely source of this allusion and used my well-developed Internet searching skills to source the song lyrics and the names of the authors - but is that a reasonable expectation?

On a personal note I have to say that the idea of being involved in a "war" against plagiarism is unhelpful. It immediately makes me think that there is a party which is "right" (those who do not commit plagiarism) and another party who is wrong (those who plagiarise). If every strategy to deal with plagiarism is a part of a battle then it feels exhausting and futile. If, instead, we conceptualise the issue of plagiarism as being about inducting scholars into the values, skills and knowledge required in order to be a valuable member of an intellectual community (as proposed by the author of Chapter 2, Laura Spencer), then the task becomes a different one.

What the book leaves unsaid is the impact on student behaviour of the practices of their institution and of the academics within it on their perceptions of acceptable practice. Many of these practices are so much a part of the fabric of the way in which a university works that they do not bear analysis (Martin, 2009). Does it make sense to have an honour code or some other overt statement of values in relation to educational integrity when, for example, research supervisors are able to gain credit for student publications to which they have may contributed little more than some routine editorial assistance?

Most of the contributing authors to this book (fourteen of the seventeen) are librarians or intimately involved in library work. So, it is probably no surprise that the role of overt teaching of the skills of accessing, appraising and applying the results of appropriately referenced sources receives strong support. There is still a lot of other useful information. It should also come as no surprise that some of that is in the form of bibliographies of resources; compiling bibliographies is something that librarians do very well. I have to admit that I am not a great fan of accompanying CD-ROMs (I suspect that early experiences of incompatible and difficult to negotiate software and sites and the requirement to load the CD-ROM each time I needed to use it because of the "managed desktop" system at my workplace were major disincentives). I am probably more inclined to use a website than an accompanying CD-ROM. However, some readers might be attracted to the CD-ROM because it enables them to visit all of the web sites referred to in the book's chapters and to view other resources made available by the editors, which might not be readily or permanently available online.

Stop Plagiarism meets its claim that it - and the accompanying CD-ROM - "are tools educators can use to teach their students the basics of intellectual honesty and to stop plagiarism" (p. ix). However, some readers might find other recent publications more accessible and relevant to their work. Examples that I have found useful include Student plagiarism in an online world: Problems and solutions, edited by Tim S.

Roberts, and Jude Carroll's A Handbook for deterring plagiarism in higher education. Another recent text that covers similar territory is Wendy Sutherland-Smith's Plagiarism, the internet and student learning: Improving academic integrity. For readability, accessibility and a non-judgmental, measured and well-evidenced approach my recommendation would be Carroll's Handbook. Readers who wish to maintain the currency and breadth of their knowledge of "plagiarism prevention" could round out this knowledge base by including Stop Plagiarism in their reading list. 


\section{About the reviewer}

Margaret Wallace is an academic developer working in the Centre for Educational Development Innovation and Recognition at the University of Wollongong to support faculties and academics in curriculum review and development. Her experience as a nursing academic and sub-dean have drawn her to undertake collaborative work with learning developers and learning designers to find ways to improve student learning. Margaret is especially interested in curriculum-integrated approaches to academic skill development and her recent publications focus on evaluations of these initiatives.

\section{References}

Bowman, V. (2004). The plagiarism plague. New York: Neal-Schuman.

Carroll, J. (2007). A handbook for deterring plagiarism in higher education, Oxford Brookes University: Oxford Centre for Staff and Learning Development.

Cvetkovic, V. \& Anderson K.E. (eds.) (2010). Stop plagiarism: A guide to understanding and prevention. New York: Neal-Schuman.

Martin, B. (2009). 'Academic patronage', International Journal of Educational Integrity. 5(1), 3-19.

Roberts, T.S. (2008). Student plagiarism in an online world: Problems and solutions. New York: Information Science Reference.

Sutherland-Smith, W. (2008.) Plagiarism, the internet and student learning. New York: Routledge. 